(c) Elsevier/INRA

Forum

\title{
Are imprinting and inbreeding two related phenomena?
}

\author{
C Biémont \\ Université Lyon 1 \\ Biométrie-Génétique et Biologie des Populations, URA 243 \\ 69622 Villeurbanne Cedex, France
}

(Received 20 June 1990; accepted 7 November 1990)

\begin{abstract}
Summary - This article presents a molecular theory of inbreeding mechanisms involving interactions between regions of the male and female genomic complement. This theory is based on the recent developments in imprinting effects on male and female gametes, which are now explained in terms of protein-DNA interactions which are manifested in some organisms in the form of cytosine methylation. Such interactions are illustrated in examples from transposable elements, which also play a key role in genetic load. This theory accounts for the effects observed in particular mating systems of inbreeding and may be of interest for heterosis as well.
\end{abstract}

inbreeding / imprinting / protein-DNA interaction / transposable element

Résumé - L'inbreeding et l'imprinting ont-ils des mécanismes communs ? Cet article présente une théorie moléculaire des mécanismes de la consanguinité basée sur l'existence d'interactions entre des zones complémentaires des génomes mâle et femelle du zygote et de l'embryon. Cette théorie s'appuie sur les récentes explications des mécanismes de l'empreinte génétique des gamètes mâle et femelle qui impliquent des interactions $A D N$ protéines dont l'une des manifestations serait la méthylation des cytosines; ces interactions joueraient un rôle fondamental au cours du développement des organismes. L'importance de telles interactions est illustrée par des exemples pris chez les éléments transposables dont le rôle comme agents mutateurs est actuellement indiscutable. Notre modèle rend compte des effets particuliers des systèmes de croisements entre parents-enfants et frèresscurs; il est aussi généralisable aux effets et mécanismes de l'hétérosis. Ce modèle doit être considéré comme une tentative d'introduire en génétique des populations nos connaissances actuelles sur la structure du génome et sa fluidité ainsi que sur les processus moléculaires intervenant au cours du développement des organismes.

consanguinité / empreinte génétique / interactions ADN-protéines / éléments transposables

\section{INTRODUCTION}

The classical theories of inbreeding effects are based on an increase in the degree of homozygosity of the inbred individuals (Wright, 1921, 1922a,b; Malécot, 1948). Inbreeding depression is thus the result of segregation at overdominant loci or of the expression of recessive deleterious or lethal alleles usually concealed in the genome (Dobzhansky et al, 1963). The high homozygosity is also believed to decrease the 
number of enzymatic paths that control metabolism (Haldane, 1954), and to perturb the system of homeostatic regulations of individuals (developmental homeostasis) as well as of populations (genetic homeostasis) which then become incapable of adapting to modifications in the environment (Lerner, 1954).

Experiments carried out on the fruit fly Drosophila and the Bruchidae Acanthoscelides obtectus, in the first generation of various inbred mating systems, have shown however that depending on the mating system used, fitness components such as egg hatchability, larvo-pupal viability, fecundity (egg production), and some other traits measured in adult flies, are not altered in the same way (Biémont, 1972a,b, 1974a, 1976; Biémont and Biémont, 1973). It was found, for example, that father-daughter matings lead to decreased larval and pupal viability and fecundity of $F_{1}$ females, whereas mother-son matings decreased embryonic mortality. Such results are not explainable globally by classical genetic theory based on simple increased homozygosity of deleterious recessive genes, even with the addition of complex cytoplasmic controls or maternal effects. The present paper is thus an attempt to present evidence regarding recent discoveries on imprinting effects and mechanisms to explain how maternal and paternal chromosome sets might be differentiated and might lead to the above inbreeding effects.

\section{THE FACTS}

It has been theoretically demonstrated that crosses between brothers and sisters, fathers and daughters, and mothers and sons, lead to the same value of the inbreeding coefficient for autosomal loci (of 1/4). An inbreeding depression of identical extent should then result in the inbred offspring of these crosses, although as postulated by Franklin (1977), the parent-child crosses should lead to less inbreeding depression than brother-sister crosses. By working on early and late development in Drosophila melanogaster, we have shown that the above 3 kinds of crosses actually give different patterns of inbreeding depression for characteristics such as egg hatchability (No of hatched eggs/No of fertilized eggs), larval and pupal viability (No of $F_{2}$ adults/No of hatched eggs), and adult egg production (total egg production during the lifetime of the $F_{2}$ adult flies, maximum egg production, longevity of the inbred adult). Tables I and II summarize the effects of the 3 mating systems on these traits. Note that total viability, which is what is usually measured, is the product of the egg hatchability by the larvo-pupal viability values. Tables I and II clearly show that fatherdaughter crosses do not decrease egg hatchability (and thus lead to a normal embryonic development), but greatly increase mortality during larval and pupal stages (table I) and decrease egg production characteristics of the adult inbred females (2 way analysis of variance: $F=4.5, P<0.05$ for total egg production; $F=8.4, P=0.008$ for maximum daily egg production). Mother-son crosses increase the embryonic mortality but have only a slight effect on larvo-pupal development (table I) and egg production measurements $(F=5.3, P<0.05$ for total egg production while there was no statistically significant difference for maximum daily egg production, $F<1$ ). Sib crosses provoke a general negative effect on all these characteristics of the inbred generations: low egg-to-adult survival (table I), low total egg production of the adult inbred females $(F=14.4, P<0.001)$, low maximum daily egg production $(F=8.4, P=0.007)$. 
Table I. Summary of inbreeding effects on egg-to-adult survival characteristics in a Drosophila melanogaster population. Egg hatchability (No of hatched eggs/No of fertile eggs) and larvo-pupal viability (No of adult offsprings/No of hatched eggs) were measured on batches of 30 eggs laid by 5-6-d-old flies. Thirty to 40 pairs were used per cross type. BS: brother-sister crosses; FD: father-daughter crosses; MS: mother-son crosses; in the control of the MS crosses, the flies were raised in the same conditions and were as old as the flies used in the inbred MS crosses. Values of the BS and FD crosses were compared by analysis of variance to the values of the parental generation; the values of the MS cross were compared to those of their control. ${ }^{* *} P<0.001$; ${ }^{* *} P<0.01$; NS: non significant. Data are from Biémont (1972a, 1972b).

\begin{tabular}{lccccc}
\hline & & \multicolumn{4}{c}{ Crosses } \\
\cline { 3 - 6 } & $\begin{array}{c}P_{0} \text { parental } \\
\text { generation }\end{array}$ & $B S$ & $F D$ & $\begin{array}{c}\text { MS } \\
\text { control }\end{array}$ & $M S$ \\
\hline Total No of & 1039 & 1234 & 844 & 886 & 1016 \\
eggs studied & 0.93 & $0.88^{* *}$ & $0.93^{\text {NS }}$ & 0.92 & $0.82^{* * *}$ \\
Egg hatchability & 0.94 & $0.80^{* * *}$ & $0.77^{* * *}$ & 0.94 & $0.88^{* *}$ \\
Larvo-pupal viability & 0.87 & $0.71^{* * *}$ & $0.72^{* * *}$ & 0.86 & $0.73^{* * *}$ \\
Total viability & & & & &
\end{tabular}

An interesting result that is worth pointing out is the observation that total viability is reduced in the same way in the 3 crosses, thus leading to the apparently similar inbreeding depression in the 3 mating systems. Because only total viability is usually determined in experiments on inbreeding, we have no other data on viability components, even in birds where parent-child crosses were experimentally analysed (Bulmer, 1973), and in which 2 developmental stages sensitive to inbreeding were reported (Lucotte, 1975). New experiments on inbreeding could then be performed in sea urchins, for example, in which embryonic development processes are now well known, and in vertebrates where many components of viability can be analysed and in which development cannot succeed satisfactorily without the paternal genome.

\section{THE INBREEDING MODEL}

The above differential effects of parent-child crosses led us to distinguish 2 phases in the way inbreeding depression takes place; a phase in which the first stages of embryonic development are perturbed and which depends on presence of a $F_{1}$ spermatozoon; and a second phase in which larvo-pupal viability and some characteristics of the $F_{2}$ offspring are perturbed, and which depends on presence of an $F_{1}$ ovum.

To explain the above results of inbreeding, we postulated that these 2 phases imply the existence of interactions between the male and female chromosomal complements in the zygote and embryo (Biémont et al, 1974; Biémont, 1974b). We then formulated the hypothesis that there exist on the male and female chromosomes particular regions capable of interacting. These regions possess some 
Table II. Summary of inbreeding effects on egg production characteristics in 2 populations of Drosophila melanogaster. Four to 10 groups of 6 vials containing 5 pairs of flies were followed per cross; egg production was recorded daily during all the lifetime of the flies. BS: brother-sister crosses; FD: father-daughter crosses; MD: mother-son crosses. $m$ : mean value; $s$ : standard error. In the control crosses, males and females were as old and were reared under the same conditions as in the associated inbred crosses. Values of each inbred cross were compared to that of each specific control by 2-way analysis of variance with the populations and the crosses as factors (see text for values). Data are from Biémont (1972b, 1974)

\begin{tabular}{lcrrrrrr}
\hline & & \multicolumn{7}{c}{ Crosses } \\
\cline { 2 - 8 } & & $\begin{array}{c}B S \\
\text { control }\end{array}$ & $\begin{array}{c}\text { BS } \\
\text { cross }\end{array}$ & $\begin{array}{c}F D \\
\text { control }\end{array}$ & $\begin{array}{c}F D \\
\text { cross }\end{array}$ & $\begin{array}{c}M S \\
\text { control }\end{array}$ & $\begin{array}{c}\text { cross } \\
\text { cross }\end{array}$ \\
\hline Strain Varces & & & & & & & \\
Total egg production & $m$ & 1790 & 1415 & 1755 & 1450 & 1830 & 1630 \\
& $s$ & 90.8 & 129.3 & 104.9 & 87.6 & 125.7 & 114.7 \\
Maximum daily & $m$ & 83.5 & 76.3 & 86.0 & 77.9 & 84.6 & 87.0 \\
egg production & $s$ & 2.1 & 3.2 & 2.8 & 3.5 & 2.9 & 3.1 \\
Strain Algérie & & & & & & & \\
Total egg production & $m$ & 1870 & 1405 & 1840 & 1413 & 1804 & 1633 \\
& $s$ & 162.8 & 58.1 & 65.2 & 160.6 & 104.2 & 92.1 \\
Maximum daily & $m$ & 83.5 & 74.5 & 81.0 & 72.0 & 84.0 & 81.5 \\
egg production & $s$ & 2.1 & 4.0 & 1.7 & 4.2 & 1.9 & 3.0 \\
\hline
\end{tabular}

sites in an active or inactive state; the inactive state needs information from the active state to become activated. What is important in this hypothesis is not only the number of active and inactive sites, but the number of interactions, $i e$, the number of couples of active-inactive homologous sites. These interactions are postulated to be necessary for complete embryonic development. Moreover, the model implies that the maternal and paternal complements are asynchronously activated so as to explain the divergence in inbreeding depression following fatherdaughter and mother-son crosses. Paternal factors are thus postulated to act first to activate the maternal complement; such interactions control embryonic development. The maternal complement acts second to activate the homologous zones on the paternal complement, and these interactions are necessary for later stages of development. Any perturbations on either the first or the second phase lead to deleterious effects on either embryonic development or late development and some adult characteristics (Biémont and Boulétreau-Merle, 1978; Biémont and Lemaitre, 1978).

It is important to note that normal development involves the confrontation of 2 gametic zones with patterns of activated/inactivated sites sufficiently different so as to have many interactions between the 2 gametic zones. The result of these interactions is, however, that the homologous complements of an adult genome are quite similar for their patterns of activated/inactivated sites, as are also the 
gametes. We can thus understand how inbred matings can lead to deleterious effects throughout development as a result of gamete incompatibility. The similarity of the homologous complements between brothers and sisters makes many interactions impossible (see the fig 1); deleterious effects for both early and late development result. In the father-daughter mating system, the pattern of active/inactive sites of the father is common to that of his daughter; nevertheless, the daughter complement contains some specific active sites not seen in her father; the interactions, thus possible, account for the normal egg hatchability observed in such a mating system, yet provoke a perturbation in late development. In the mother-son crosses, the interactions involved are opposite to that of the father-daughter crosses; hence, the opposite effects are observed in this mother-son mating system: embryonic development is perturbed while the later developmental stages are almost normal.

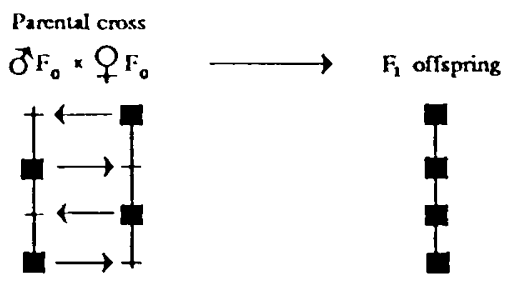

Nomal development

INBRED CROSS

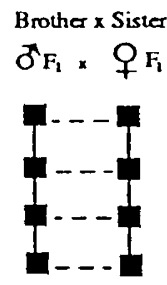

- Early and late developments perturbed

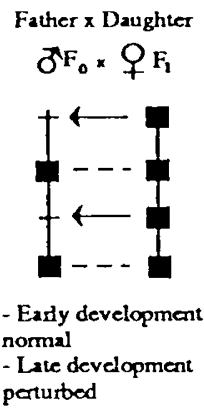

Son $x$ Mother

$\delta_{\mathrm{K}} \times \mathrm{QF}_{\mathrm{O}}$

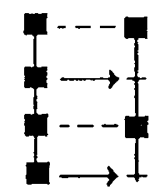

- Early development perturbed

- Late development normal

Fig 1. Schematic patterns of active/inactive site interactions between the genomic complements, for a parental random cross and 3 mating systems (brother-sister, father-daughter, mother-son). The arrows indicate the interactions between activated and inactivated regions of the chromosomes; dotted lines correspond to the absence of interaction between sites in the same state. The direction of the arrows from the paternal to the maternal complements and vice versa, determines which stage of development (early or late) is perturbed. Note the identity in patterns of the 2 genomic complements after the interactions have occurred; since development is not blocked entirely (after sib crosses for example), some spontaneous deactivation or errors in the activation process must exist, allowing some sites to interact.

As a result of the site interactions, the 2 genomic complements have similar patterns of activated/inactivated sites along the chromosome; spontaneous changes in such patterns must then exist to allow some interactions to proceed, avoiding 
thus a complete blocking of development. Variation in intensity of such a process accounts for the differential responses to inbreeding of organisms.

Note that in the years 1973-1974 no molecular knowledge was available to render the above hypotheses testable and acceptable by the scientific community. Indeed, little was known on how the genes were activated and regulated throughout development, and repression of gene expression by non-histone chromosomal proteins was only mentioned (Spiegel et al, 1970; Asao, 1972; Kostraba and Wang, 1973; Stein et al, 1974). The recognition of the existence of a phenomenon termed "imprinting" by Crouse (1960) was required in order to distinguish between maternal and paternal chromosome complements in many processes such as specific chromosomal elimination and inactivation by heterochromatization in various organisms. In 1975, Holliday and Pugh (1975) presented their theory of imprinting based on proteinDNA interaction and cytosine methylation. In the following sections, I summarize our current knowledge on this very exciting phenomenon of imprinting and discuss its importance and pertinence for the above model of inbreeding mechanisms.

\section{IMPRINTING}

Heterochromatization and chromosome elimination in many organisms have in common the selective silencing by inactivation or elimination of specific chromosomes or parts of chromosomes in the presence of unaffected homologs.

The sex chromosomes of paternal origin are eliminated in ratlike bandicoots, inactivated in kangaroos while random inactivation occurs in placental mammals (Lyon, 1961; Sharman, 1971). In the coccids, Hemiptera, the chromosomes of paternal origin are inactivated or eliminated. For example, in lecanoids the paternally derived chromosomal set becomes heterochromatic and functionally inactive and remains so in most tissues throughout development (Brown and Nelson-Rees, 1961; Brown and Nur, 1964; Nur, 1967; Brown and Wiegmann, 1969; Kitchin, 1970; Sabour, 1972; Berlowitz, 1974); in diaspidids the effective haploidization of the male is accomplished by elimination of the paternal chromosomal set. In the olive scale insect Parlatoria olea (Kitchin, 1970) the heterochromatic chromosomes disappear by intranuclear destruction in the primary spermatocyte shortly before meiosis. Oogenesis is normal in Sciara where the egg receives a haploid set of autosomes and one X chromosome (Crouse et al, 1971), but in spermatogenesis the paternally derived X chromosome and autosomes are discarded (Crouse et al, 1971; Sager and Lane, 1972); the male transmits through the sperm only the chromosomes that he received from his mother. In Chlamydomonas, the chloroplast genome from the male parent is not transmitted because it disappears soon after zygote formation (Sager, 1972; Sager and Ramanis, 1974).

Hence, a phenomenon is required to distinguish between the maternal and paternal chromosome complements. Crouse (1960) has used the term imprinting to describe the alteration which allows a given chromosome to be distinguished from its homolog. Preferential expression of maternal or paternal genes throughout development in some species (Courtright, 1967; Dickinson, 1968; Wright et al, 1972; Sayles et al, 1973; Shannon, 1973) or in interspecific hybrids (Whitt et al, 1972) is also a good example of imprinting. 
According to Surani and Barton (1984) and Surani et al (1984), genomic imprinting could confer on some elements of the genome of reproductive cells a memory of their parental origin, so that the chromosomes or certain genes are marked by their path through the father and the mother. The maternal and paternal genomes may "remember" this parental origin throughout the development and life of the individuals. The simultaneous presence of the 2 chromosomal complements marked by the father and the mother are necessary for the embryonic development to be complete (Surani and Barton, 1984; Surani et al, 1984; Modlinski, 1980). From all these studies it appears that the paternal genome is more important for development of extra-embryonic tissues while the maternal complement is necessary for embryonic development. Brown and Chandra (1973) proposed for mammals the existence of sensitive sites subject to imprinting, which activate receptor sites, which in turn, regulate heterochromatization of the X chromosome.

It has been shown in animals that for particular chromosomal regions with maternal duplication/paternal deficiency and its reciprocal, anomalous phenotypes depart from normal in opposite directions (Cattanach and Kirck, 1985). Such departure suggests a differential functioning of some gene loci within this region and also suggests the existence of a form of chromosome imprinting that affects gene activity. According to these authors, the male chromosomal region may thus have a single or earlier activity while inactivity or later activity may be a characteristic of the corresponding female region.

\section{PROTEIN-DNA INTERACTIONS AND DNA METHYLATION}

The mode of action of genes during development of the organism from the egg to adult is very poorly understood, and the changes in gene activity throughout development are generally referred to as epigenetic (Waddington, 1965). It is usually believed that specific protein-DNA interactions are responsible for such epigenetic changes in gene activity.

It has been shown that such imprinting is associated with DNA methylation, which is a key element in the control mechanisms that govern gene function and differentiation (Razin and Riggs, 1980; Kolata, 1985; Reik et al, 1987; Sapienza et al, 1987). In eukaryotic methylation, certain cytosines are converted to 5methylcytosine which acts just like a new DNA base. Holliday and Pugh (1975), Riggs (1975) and Holliday (1987) have proposed that methylation is heritable, passed on from generation to generation as cells divide (Kolata, 1985; Reik et al, 1987; Sapienza et al, 1987); their proposition was further verified and suggests the existence of specific factors (maintenance methylase) (Harrison and Karrer, 1989) capable of recognizing the hemimethylated DNA formed after replication and that can methylate the nascent DNA strands (Holliday and Pugh, 1975; Riggs, 1975). Holliday (1987) then postulated that loss of methylation, which can result from DNA damage, leads to heritable abnormalities in gene expression. Such epigenetic defects in germline cells as a result of this loss of methylation can be repaired by recombination at meiosis, but some are transmitted to offspring. Defects that are not repaired at meiosis will have properties formally equivalent to mutations, since they are heritable and can have specific phenotypic effects. When heterozygous, an epigenetic defect can then be converted to wild type by recombination at meiosis 
(Holliday, 1987); the defects are thus "eliminated" by meiosis. With inbreeding, however, some epigenetic defects will become homozygous and will stay in this state throughout generations, depending on their probability of being removed as heterozygotes at meiosis. Holliday thus proposed that such processes could explain inbreeding effects.

According to Sager and Kitchin (1975) differential heterochromatization and chromosome elimination are regulated by modification of DNA by enzymes, as is the case in bacterial systems (Luria and Human, 1952), with specificity for particular recognition sites. It is postulated that the modification enzymes protect the recognition sites by DNA methylation from attack by the endonucleases.

Razin and Riggs (1980) proposed that methylation could also lock nucleosomes into position on the DNA, the control regions of active genes not wound up in these nucleosomes being fixed by this methylation process until a new state of differentiation is established. This agrees with the observation that nucleosome positions on the DNA vary according to the state of differentiation of the cell. In such a model, methylation is only a secondary controller of gene expression, the primary stage being assumed by some kind of "determinator" proteins (Razin and Riggs, 1980).

It is striking that researchers have not yet found the enzymes that originally add methyl groups to DNA in genes which are then permanently turned off during development; only "maintenance" enzymes (Harrison and Karrer, 1989) keeping methyl groups on during cell division are known. Note that the functional differences between maternal and paternal nuclei were found to be retained after the activation of the embryonic genome at the 2-cell stage (Surani et al, 1986), although the somatic methylation pattern has been found in 3-d embryos of chickens, in clusters of repeated DNA sequences (Sobieski and Eden, 1981).

Although it now appears that DNA methylation plays an important role in gene expression during development, some organisms manage quite well without any extensive methylation. The mechanisms for marking expressed genes in such organisms are still unknown. Lower vertebrates in general have far less methylation than mammals. Twenty percent of the lower vertebrate DNA is methylated as compared to $80 \%$ in mammalian DNA, and the DNA of the fruit fly does not seem to be methylated at all (Bird, 1980, 1984). It is possible that some specific protein-DNA interactions, which are associated in higher organisms with the methylation pattern, survive to transmit the memory, and that these interactions alone are sufficient to account for imprinting in Drosophila (Razin and Riggs, 1980). Such DNA-protein interactions have been suggested to be themselves heritable (Weintraub, 1985). The lack of methylation in Drosophila may at first sight eliminate this species as a candidate for imprinting, but remember that preferential expression of some paternal and maternal genes occurs during development in Drosophila melanogaster (Courtright, 1967; Dickinson, 1968; Wright et al, 1972; Sayles et al, 1973; Shannon, 1973). Moreover, as noted above, the genome imprinting process was first discovered in various invertebrates, but the methylation of cytosine has not yet been searched for in most of the organisms. 


\section{THE TRANSPOSONS}

Transposable elements have recently been shown to be submitted to a regulation system involving methylation. Because of their effects on genes and their ability to induce chromosomal rearrangements, these elements are an important source of genetic variability (Syvanen, 1974) and thus participate in the genetic load (Mukai and Yukuhiro, 1983; Biémont et al, 1985; Yukuhiro et al, 1985; Fitzpatrick and Sved, 1986; Mackay, 1986). Transposition rates are usually found to be $\approx 10^{-3}$ per generation (Pierce and Lucchesi, 1981; Young and Schwartz, 1981) but higher rates of transposition can be obtained either in crosses between certain strains of Drosophila melanogaster (Brégliano and Kidwell, 1983) or under particular conditions (Gerasimova et al, 1983; Junakovic et al, 1986). Although in the long run an elevated mutation rate could be advantageous for population adaptation (Biémont et al, 1984; Georgiev, 1984), the potentially harmful effects of high rates of transposition may lead to selection for some mechanisms that regulate the activity of the transposable elements.

The controlling element $A c$ (activator) in Zea mays is capable of transposition, and a derivative that has lost transposase activity has been shown to have methylated cytosine that is inherited through sexual crosses; this inactive element can revert to active $A c$ by loss of methylation (Kunze et al, 1988). The activities of this maize transposable element $A c$, as well as $\operatorname{Spm}(E n)$, are thus correlated with hypomethylation (Burr and Burr, 1981; Dellaporta and Chomet, 1985; Chomet et al, 1987; Fedoroff et al, 1988; Raboy et al, 1988). DNA methylation of the maize transposable element $A c$ interferes with its transcription. In the inactive phase, the $A c$ DNA is highly methylated and no $A c$ transcript is detectable (Kunze et al, 1988).

In the same way, the majority of $M u$ elements in the maize genome are unmethylated in active stocks and methylated in inactive stocks (Schwartz and Dennis, 1986; Bennetzen, 1987; Bennetzen et al, 1988). An interesting observation is that intercrossing diverse mutator lines of maize leads to a discrete hypermodification of the $M u$ elements with a loss of mutagenic and transpositional potential (Bennetzen et al, 1987). Modification of $M u$ elements may block their ability to interact with a putative transposase as is the case with the IS 10 element in prokaryotes which is regulated by adenosine methylation (Roberts et al, 1985).

In mice, methylation concerns some but not all copies of the IAP repetitive sequences (Mays-Hoopes et al, 1983). In the L1 element family, concerted hypomethylation of sequences has been observed in mouse extraembryonic cells and in transformed cell lines (Tolberg et al, 1987). It is thus speculated that in L1, methylation may modulate transcription of some selected sites.

Thus DNA methylation may be a mechanism for heritably controlling genetic element transposition. Such modification may be one mechanism regulating the possible deleterious activity in the cell (Chandler and Walbot, 1986). Transposition rate may also be under genetic control as in the switch in mating type of yeasts, which is normally confined to the mother cell lineage (Hicks et al, 1977). Whether mobile elements are really involved in an imprinting phenomenon is not yet clear, but this merits further investigation, especially since the sequence methylation pattern of the spm element in maize can be both reset and heritably reprogrammed 
during development, and such elements have a differential probability of being inactivated upon transmission through male or female gametes (Fedoroff, 1989).

\section{A UNIFIED THEORY}

It is still a matter of speculation as to whether the effects of inbreeding are due mainly to loss of homeostatic capacity of the more homozygous individuals or to the effects of recessive deleterious factors present in all wild chromosomes and exposed by the increasing homozygosity of the genome. The inbreeding depression thus results in a low viability due to numerous causes of mortality throughout the development of the organism (Lewontin, 1974); viability has thus been postulated to be controlled by polygenes with an extremely high spontaneous mutation rate (Simmons and Crow, 1977). From the above considerations, we now propose that inbreeding interferes with, or is strongly connected with mechanisms controlling embryonic development. Such an inbreeding model does not of course eliminate the classical hypotheses (Wright, 1921, 1922a,b; Malécot, 1948; Haldane, 1954; Lerner, 1954; Dobzhansky et al, 1963); the inbreeding depression reported throughout development in many organisms surely involves more than 1 mechanism.

Inbreeding and imprinting have common bases:

- the molecular memory of parental origins of the maternal and paternal genomic complements,

- the necessity of the simultaneous presence of the chromosomal complements marked by the father and the mother for the embryonic development to be complete; hence the existence of interactions between the 2 chromosomal sets,

- the occurrence of sensitive sites which activate receptor sites in imprinting, or of interactions between activated and inactivated sites in inbreeding,

- a differential activity during development of the male and female complements,

- the existence of some spontanous site deactivation, or errors in the activation process, which avoid a complete blocking of development from the first generation of inbreeding on. Note that this latter consideration agrees well with the ideas that changes in protein/DNA interaction pattern can lead to heritable abnormalities in gene expression (Holliday, 1987), and that some specific interactions which survive to transmit the memory can themselves be heritable (Weintraub, 1985); it is also supported by the recent observation of the failure of the germline in mice to erase the epigenetic modifications at the TKZ751 locus, thus leading to cumulative modifications of this locus through successive generations (Allen et al, 1990).

Hence, inbreeding depression viewed in terms of interactions between the 2 parental chromosomal sets as occurs in imprinting is more a quantitative than a qualitative modification of a process existing normally in non-inbred individuals. The number of interactions involved in development is merely lowered by inbreeding, thus resulting in a higher probability for abnormal development. Such a quantitative effect agrees with the observation of an increased amount of histone proteins in inbred lines of rye (Kirk and Jones, 1974) and a disappearance of some biochemical components in Drosophila (Hoenigsberg and Castiglioni, 1958; King, 1969), as could result if inbreeding is associated with an increased repression of gene activity. 
According to our model, the absence of interaction between 2 related gametic chromosomal complements blocks the first stages of embryonic development. But a population submitted to strong inbreeding such as brother-sister matings does not disappear in the first generations as could result due to null fitness. Even in the species most sensitive to inbreeding such as Gallinacea, 3 inbred generations are necessary for the population to collapse (Cole and Halpin, 1916; Dunn, 1928). Thus some spontaneous changes in the pattern of activated/inactivated sites along the chromosomal sets are needed to permit some interactions without blocking development entirely. Such changes in pattern could happen as a result of error in either the methylation process or the protein-DNA interactions involved in the imprinting mechanism. These spontaneous modifications and also the variation in the number of sites interacting could be responsible for the divergence existing between inbred individuals and among sublines.

Indeed, a problem in mouse genetics is the unexpected variation in homozygous inbred animals. For example, the frequency of variation of some skeletal structures is far higher than expected from classical mutation rates. Subline differentiation is a continuing process, the frequency of changes per variant being as high as 0.01 per generation (Hoi-Sen, 1972), 1000 times as common as the average mutation rate for a number of genes in the mouse (Schlager and Dickic, 1967). Murphy (1966), moreover, described a high frequency of tumors in 16 major inbred mouse stocks, as if inbreeding caused an increased rate of tumorigenesis.

Fitch and Atchley (1985) supposed that if a mutation process, such as conversion or switching, were to occur to explain subline divergence in nice, it would be as high as $10^{-3}$, a rate similar to that observed in switching on and off loci responsible for phase variation in Salmonella. Such a rate of $10^{-3}$ is exactly the average value of transposition rate found in Drosophila for transposable elements (Pierce and Lucchesi, 1981; Young and Schwartz, 1981), even in highly inbred lines maintained by systematic brother-sister mating during $\approx 108$ generations (data on $\mathrm{mdg}-1$ and $P$ elements; unpublished results). Holliday (1987) has thus postulated that such morphological variation is due to heritable modification of germline DNA. There is, however, no evidence of a high visible mutation rate in mouse inbred lines (Johnson et al, 1981). It may thus be that the factors promoting line divergence do not always lead to emergence of visible and detectable mutations, as if only some particular regions of the chromosomes were concerned.

Our inbreeding model fits the data on heterosis as well, with fitness values being correlated with the number of interacting sites (Biémont, 1974b, 1980; Biémont et $a l, 1974)$. The more the lines diverge the higher the number of interactions resulting from their crossing: a high value of fitness of the hybrid should result. Because many interacting sites are concerned, crossing sibs of such hybrids should lead to a strong inbreeding depression, as experimentally observed (Falconer, 1981). Such processes recall a heterosis model of self-incompatibility based on prezygotic expression of genetic load mediated through pollen-style interactions determined by the genotype of the 2 parents (Mulcahy and Mulcahy, 1983).

A mathematical analysis of the interaction system has been developed with sib matings (Biémont, 1974b, 1980; Biémont et al, 1974). This probabilistic approach gives the tendencies for inbreeding depression, measured by the viability value, with generations of inbreeding; the tendencies are compatible with the experimental 
observations: a deleterious effect of inbreeding is usually observed which can even lead to line extinction, depending on the values of the model parameters. It has been observed that inbreeding depression generally decreases with generations and leads to stable lines (King, 1918; Wright, 1922a,b; Wright and Heaton, 1922; Hyde, 1924; Petit, 1963; Ootmersen, 1970; Legay, 1971; Kosuda, 1972). This asymptotic value could correspond to the "inbred minimum" reported by King (1918) in certain species of rodents. Beneficial or neutral effects can also be obtained with the model, as sometimes experimentally reported (Castle and Carpentier, 1906; Rasmusson, 1951; Lints, 1961). One problem with our model is that it requires spontaneous changes in state (active/inactive) with a higher rate than that usual for mutations. This problem now seems to be overcome since processes such as transposition of mobile elements have a rate in the order of $10^{-3}$ or even more, and it appears quite reasonable that change in methylation pattern may be modified with an elevated rate, at least under some conditions. For example, $M u$ elements in maize may become modified after self-pollination (Chandler and Walbot, 1986) or inbreeding of mutator stocks (stocks with high rate of mutations and presence of active $M u$ transposons) (Bennetzen, 1987; Bennetzen et al, 1988), and such modifications are correlated with lack of activity (Chandler et al, 1988).

\section{CONCLUSION}

It is clear that the kind of interactions between the 2 chromosomal complements is one of the numerous facts in genome structuring and functioning that population genetics should take into account in the near future. Even so, as stated by Lewontin (1985), the existence of such phenomena does not in itself guarantee their importance to population genetic considerations, although a recent mathematical approach tends to demonstrate the potential population genetic consequences of molecular imprinting: apparent heterozygote deficiency and a concurrent hybrid vigor (Chakraborty, 1989). The knowledge of the fine structure of these phenomena may lead to the wish that, by changing the environmental and physiological conditions, they could be acted upon and their effects modified in some way; they would then become of considerable importance for population genetics, applied quantitative genetics and evolutionary biology.

\section{ACKNOWLEDGMENTS}

We thank C Arnault, P Caruso, JR David, C Gauthier, R Grantham, A Heizmann, JM Legay and D Pontier for their useful comments. This work was supported by the Centre National de la Recherche Scientifique (URA 243), the Association pour la Recherche sur le Cancer, and the Hasselblad Foundation.

\section{REFERENCES}

Allen ND, Norris ML, Surani MA (1990) Epigenetic control of transgene expression and imprinting by genotype-specific modifiers. Cell 61, 853-861 
Asao $\mathrm{T}$ (1972) Origin of histones and relation between nuclear histones and cytoplasmic basic proteins in early development of Japanese newt, Triturus pyrrhogaster. Exp Cell Res 73, 73-80

Bennetzen JL (1987) Covalent DNA modification and the regulation of mutator element transposition in maize. Mol Gen Genet 208, 45-51

Bennetzen JL, Fracasso RP, Morris DW, Robertson DS, Skogen-Hagenson MJ (1987) Concomitant regulation of $M u 1$ transposition and mutator activity in maize. Mol Gen Genet 208, 57-62

Bennetzen JL, Brown WE, Springer PS (1988) DNA modification within and flanking maize-transposable elements: In: Plant Transposable Elements (Nelson OE, Jr, ed) Plenum Press, NY, 237-250

Berlowitz I (1974) Chromosomal inactivation and reactivation in mealy bugs. Genetics 78, 311-322

Biémont C (1972a) Effets différents sur la fertilité de trois croisements conduisant au même degré de consanguinité chez Drosophila melanogaster. $C R$ Séances Acad Sci 275, 1079-1082

Biémont C (1972b) Etude des effets de la consanguinité au niveau de certains caractères physiologiques chez Drosophila melanogaster Meig. Doctoral Thesis No 187, Lyon

Biémont C (1974a) Analyse de descendances inbred de Drosophila melanogaster, en fonction du type de croisement. C R Séances Acad Sci 278, 1095-1098

Biémont $\mathrm{C}$ (1974b) A chromosomal interaction system for the control of embryonic development. Mech Ageing Dev 3, 291-299

Biémont C (1976) Maternal effects and inbreeding insensitivity in embryos of Drosophila melanogaster. Naturwissenschaften 63, 199-200

Biémont C (1980) An inbreeding sensitivity gene in Drosophila melanogaster. Experientia $36,169-170$

Biémont JC, Biémont C (1973) Réponses différentes de la fertilité d'Acanthoscelides obtectus à deux croisements consanguins frère-sœur et père-fille. $C R$ Séances Acad Sci 276, 2593-2595

Biémont C, Boulétreau-Merle J (1978) Inbreeding effects: embryonic development and fecundity of Drosophila melanogaster populations. Experientia 34, 1273-1274

Biémont C, Lemaitre C (1978) Les effets de la consanguinité chez Drosophila melanogaster: influence du développement embryonnaire sur la thermogenèse des descendants. $C R$ Séances Acad Sci 286, 1715-1717

Biémont C, Bouffette AR, Bouffette J (1974) Théorie chromosomique de l'inbreeding. Modèle probabiliste. Bull Math Biol 36, 417-434

Biémont C, Belyaeva ESp, Pasyukova ES, Kogan G, Gvozdev VA (1985) Mobile gene localization and viability in Drosophila melanogaster. Experientia 41, 1474-1476

Biémont C, Aouar A, Arnault C (1987) Genome reshuffling of the copia element in a Drosophila melanogaster inbred line. Nature 329, 742-744

Bird AP (1980) DNA methylation and the frequency of CpG in animal DNA. Nucleic Acids Res 8, 1499-1504

Bird AP (1984) DNA methylation-how important in gene control. Nature 307, 503504 
Brégliano JC, Kidwell MG (1983) Hybrid dysgenesis determinants: In: Mobile Genetic Elements (Shapiro, JA ed) Acad Press, NY, 363-410

Brown SW, Nelson-Rees WA (1961) Radiation analysis of a lecanoid genetic system. Genetics 46, 983-1007

Brown SW, Nur U (1964) Heterochromatic chromosomes in the coccids. Science $145,130-136$

Brown SW, Wiegmann LI (1969) Cytogenetics of the mealybug Planococcus citri (Risso) (Homoptera: Coccoidea). Chromosoma 28, 255-279

Brown SW, Chandra HS (1973) Inactivation system of the mammalian X chromosome. Proc Natl Acad Sci USA 70, 195-199

Bulmer MG (1973) Inbreeding in the great tit. Heredity 30, 313-325

Burr B, Burr F (1981) Transposable elements and genetic instabilities in crop plants. Stadler Genet Symp 13, 115-128

Castle WE, Carpenter FW (1906) The effect of inbreeding, crossbreeding and selection upon the fertility and viability of Drosophila. Proc Am Acad Arts Sci 41, 729-786

Cattanach BM, Kirck M (1985) Differential activity of maternally and paternally derived chromosome regions in mice. Nature $315,496-498$

Chandler V, Walbot V (1986) DNA modification of a maize transposable element correlates with loss of activity. Proc Natl Acad Sci USA 83, 1767-1771

Chandler VL, Talbert LE, Raymond F (1988) Sequence, genomic distribution and DNA modification of a $M u 1$ element from non-mutator maize stocks. Genetics 119 , 951-958

Chakraborty R (1989) Can molecular imprinting explain heterozygote deficiency and hybrid vigor? Genetics 122, 713-717

Chomet PS, Wessler S, Dellaporta SL (1987) Inactivation of the maize transposable element activator $(A C)$ associated with DNA modification. EMBO J 6, 295-302

Cole LJ, Halpin JG (1916) Preliminary report of an experiment on close inbreeding in fowls. $J$ Am Ass Instructions Investigation 3, 7-8

Courtright JB (1967) Polygenic control of aldehyde oxidase in Drosophila. Genetics $57,25-39$

Crouse HV (1960) The controlling element in sex chromosome behavior in Sciara. Genetics 45, 1429-1443

Crouse HV, Brown A, Mumford BC (1971) L-chromosome inheritance and the problem of chromosome imprinting in Sciara (Sciaridae, Diptera). Chromosoma 34, 324-339

Dellaporta SL, Chomet PS (.985) The activation of maize controlling elements. In: Plant Gene Research: Genetic Flux in Plants (Hohn B, Dennis, ES eds) Springer Verlag, NY, 170-217

Dickinson WJ (1968) Genetic and developmental regulation of aldehyde oxidase in Drosophila melanogaster. Genetics (abstr) 60, 173

Dobzhansky T, Spassky B, Tidwell T (1963) Genetics of natural populations. XXXII. Inbreeding and the mutational and balanced genetic loads in natural populations of Drosophila pseudoobscura. Genetics 48, 361-373

Dunn LC (1928) The effect of inbreeding and cross breeding on fowls. Int Kongr Vererbungsw (Berl) 1, 609-617 
Falconer DS (1981) Introduction to Quantitative Genetics. Oliver \& Boyd, Edinburgh

Fedoroff NV (1989) About maize transposable elements and development. Cell 56, 181-191

Federoff N, Masson P, Banks J, Kingsbury J (1988) Positive and negative regulation of the suppressor-mutator element: In: Plant Transposable Elements (Nelson OE Jr, ed) Plenum Press, NY, 1-15

Fitch WM, Atchley WR (1985) Evolution in inbred strains of mice appears rapid. Science 228, 1169-1175

Fitzpatrick BJ, Sved JA (1986) High levels of fitness modifiers induced by hybrid dysgenesis in Drosophila melanogaster. Genet Res (Camb) 48, 89-94

Franklin IR (1977) The distribution of the proportion of the genome which is homozygous by descent in inbred individuals. Theor Popul Biol 11, 60-80

Georgiev GP (1984) Mobile genetic elements in animal cells and their biological significance. Eur J Biochem 145, 203-220

Gerasimova TI, Mizrokhi LJ, Georgiev G (1983) Transposition bursts in genetically unstable Drosophila melanogaster. Nature 309, 714-716

Haldane JBS (1954) The Biochemistry of Genetics. Allen \& Unwin, London

Harrison GS, Karrer KM (1989) Methylation of replicating and nonreplicating DNA in the ciliate Tetrahymena thermophila. Mol Cell Biol 9, 828-830

Hicks JB, Strathern JN, Herskowitz I (1977) DNA Insertion Elements, Plasmids and Episomes (Bukhari et al, eds) Cold Spring Harbor Lab, NY

Hoenigsberg HF, Castiglioni MC (1958) Biochemical differences between inbred and outbred lines of Drosophila melanogaster studied by paper partition chromatography. Nature 181, 1404

Hoi-Sen JY (1972) Is subline differentiation a continuing process in inbred strains of mice? Genet Res (Camb) 19, 53-59

Holliday R (1987) The inheritance of epigenetic defects. Science 238, 163-170

Holliday R, Pugh JE (1975) DNA modification mechanisms and gene activity during development. Science 187, 226-232

Hyde RP (1924) Inbreeding, outbreeding. J Exp Zool 26, 3-54

Johnson FM, Roberts GT, Sharma RK, Chasalow F, Zweidinger R, Morgan A, Hendren RW, Lewis SE (1981) The detection of mutants in mice by electrophoresis: results of a model induction experiment with procarbazine. Genetics $97,113-124$

Junakovic. N, Di Franco C, Barsanti P, Palumbo G (1986) Transposition of copialike nomadic elements can be induced by heat shock. $J$ Mol Evol 24, 89-93

King HD (1918) Studies on inbreeding. J Exp Zool 26, 3-54

King JC (1969) Differences in levels of xanthine dehydrogenase activity between inbred and outbred strains of Drosophila melanogaster. Proc Natl Acad Sci USA $64,891-896$

Kirk DJ, Jones RN (1974) Quantitative nuclear variation in inbred lines and hybrid rye. Heredity $32,357-373$

Kitchin M (1970) A radiation analysis of a Comstockiella chromosome system: destruction of heterochromatic chromosomes during spermatogenesis in Parlatoria oleae (Coccoidea: Diaspididae). Chromosoma 31, 165-197

Kolata G (1985) Fitting methylation into development. Science 228, 1183-1184 
Kostraba NC, Wang TY (1973) Non-histone proteins and gene activation in regenerating rate liver. Exp Cell Res 80, 291-296

Kosuda K (1972) Synergistic effect of inbreeding on viability in Drosophila virilis. Genetics 72, 461-468

Kunze R, Starlinger P, Schwartz D (1988) DNA methylation of the maize transposable element $A c$ interferes with its transcription. Mol Gen Genet 214, 325-327 Legay JM (1971) Effets de la consanguinité sur deux caractères quantitatifs chez le vers à soie. Ann Génét Sél Anim 34, 487-495

Lerner IM (1954) Genetic Homeostasis. Oliver \& Boyd, Edinburgh

Lewontin RC (1974) The Genetic Basis of Evolutionary Changes. Columbia Univ Press, NY

Lewontin RC (1985) Population genetics. Ann Rev Genet 19, 81-102

Lints FA (1961) Diversity by inbreeding in Drosophila. Genetica 32, 177-199

Lucotte G (1975) Le fardeau génétique chez la caille japonaise. Ann Biol 14, 167-182 Luria SE, Human ML (1952) A nonhereditary, host-induced variation of bacterial viruses. J Bacteriol 64, 557-569

Lyon MF (1961) Gene action in the X-chromosome of the mouse (Mus musculus L) Nature $190,372-373$

Mackay TFC (1986) Transposable element-induced fitness mutations in Drosophila melanogaster. Genet Res (Camb) 48, 77-87

Malécot G (1948) Les Mathématiques de l'Hérédité. Masson, Paris

Mays-Hoopes LL, Brown A, Huang RCC (1983) Methylation and rearrangement of mouse intracisternal A particle genes in development, aging, and myeloma. Mol Cell Biol 3, 1371-1380

Modlinski JA (1980) Preimplantation development of microsurgically obtained haploid and homozygous diploid mouse embryos and effects of pretreatment with cytochalasin B on enucleated eggs. J Embryol Exp Morphol 60, 153-161

Mukai T, Yukuhiro K (1983) An extremely high rate of deleterious viability mutations in Drosophila possibly caused by transposons in non-coding regions. Proc Jpn Acad Ser B Phys Biol Sci 59, 316-319

Mulcahy DL, Mulcahy GB (1983) Gametophytic self-incompatibility reexamined. Science 220, 1247-1251

Murphy ED (1966) In: Biology of the Laboratory Mouse (Green EL, ed) McGrawHill, NY, 521

Nur U (1967) Reversal of heterochromatization and the activity of the paternal chromosome set in the male mealybug. Genetics 56, 375-389

Ootmersen GA (1970) Biolnçical significance, genetics and evolutionary origin of variability in behaviour within and between inbred strains of mice. Behaviour 1, 1-92

Petit C (1963) L'influence du mode de croisement sur la structure génétique des populations: la stabilité des populations expérimentales de faible effectif. Ann Génét $6,29-35$

Pierce DA, Lucchesi JC (1981) Analysis of a dispersed repetitive DNA sequence in isogenic lines of Drosophila melanogaster. Chromosoma 82, 471-492

Raboy V, Schiefelbein JW, Nelson OE (1988) DNA modification and the timing of defective Spm excision from the bz-ml13 allele in maize. In: Plant Transposable Elements (Nelson OE Jr, ed) Plenum Press, NY, 376-377 
Rasmusson M (1951) Variation in inbred lines of Drosophila melanogaster. Heredity 37, 561-563

Razin A, Riggs AD (1980) DNA methylation and gene function. Science 210, 604-610

Reik W, Collick A, Norris ML, Barton SC, Surani MAH (1987) Genomic imprinting determines methylation of parental alleles in transgenic mice. Nature 328, 248-251 Riggs AD (1975) X inactivation, differentiation, and DNA methylation. Cytogenet Cell Genet 14, 9-25

Roberts D, Hoopes BC, McClure WR, Kleckner N (1985) IS10 transposition is regulated by DNA adenine methylation. Cell 43, 117-130

Sabour M (1972) RNA synthesis and heterochromatization in early development of a mealybug. Genetics 70, 291-298

Sager R (1972) Cytoplasmic Genes and Organelles. Academic Press, NY

Sager R, Lane D (1972) Molecular basis of maternal inheritance. Proc Natl Acad Sci USA 69, 2410-2413

Sager R, Ramanis Z (1974) The mechanism of maternal inheritance in Chlamydomonas: biochemical and genetic studies. Theor Appl Genet 43, 101-108

Sager R, Kitchin R (1975) Selective silencing of eukaryotic DNA. Science 189, 426433

Sapienza C, Peterson AC, Rossant J, Balling R (1987) Degree of methylation of transgenes is dependent on gamete of origin. Nature 328, 251-254

Sayles CD, Browder LW, Williamson JH (1973) Expression of xanthine dehydrogenase activity during development of Drosophila melanogaster. Dev Biol 33, 213-217

Schlager G, Dickic MM (1967) Spontaneous mutations and mutation rates in the house mouse. Genetics 57, 319-330

Schwartz D, Dennis E (1986) Transposase activity of the $A c$ controlling element in maize is regulated by its degree of methylation. Mol Gen Genet 205, 476-482

Shannon MP (1973) The development of eggs produced by the female sterile mutant Almondex of Drosophila melanogaster. J Exp Zool 183, 383-400

Sharman GB (1971) Late DNA replication in the paternally derived chromosome of female kangaroos. Nature 230, 231-232

Simmons MJ, Crow JF (1977) Mutations affecting fitness in Drosophila populations Ann Rev Genet 11, 49-78

Sobieski DA, Eden FC (1981) Clustering and methylation of repeated DNA: persistence in avian development and evolution. Nucleic Acids Res 9, 6001-6015

Spiegel M, Spiegel ES, Meltzer PS (1970) Qualitative changes in the basic protein fraction of developing embryos. Dev Biol 21, 73-86

Stein GS, Spelsberg TC, Kleinsmith LJ (1974) Nonhistone chromosomal proteins and gene regulation. Science 183, 817-824

Surani MAH, Barton SC (1984) Development of gynogenetic eggs in the mouse: implications for parthenogenetic embryos. Science 222, 1034-1036

Surani MAH, Barton SC, Norris ML (1984) Development of reconstituted mouse eggs suggesting imprinting of the genome during gametogenesis. Nature 308, 548550

Surani MAH, Barton SC, Norris ML (1986) Nuclear transplantation in the mouse: heritable differences between parental genomes after activation of the embryonic genome. Cell 45, 127-136 
Syvanen JM (1974) The evolutionary implications of mobile genetic elements. Annu Rev Genet 18, 271-293

Tolberg ME, Funderburk SJ, Klisak I, Smith SS (1987) Structural organization and DNA methylation patterning within the mouse L1 family. $J$ Biol Chem 262, 11167-11175

Waddington CH (1956) Principles of Embryology. Allen \& Unwin, London Weintraub $\mathrm{H}$ (1985) Assembly and propagation of repressed and derepressed chromosomal states. Cell 42, 705-711

Whitt GS, Cho PL, Childers WF (1972) Preferential inhibition of allelic isozyme synthesis in an interspecific sunfish hybrid. $J$ Exp Zool 179, 271-282

Wright S (1921) Systems of mating. Genetics 6, 111-178

Wright S (1922a) Coefficient of inbreeding and relationships. Am Nat 56, 330-338

Wright S (1922b) The effects of inbreeding and crossbreeding on guinea pigs. Decline in vigour. II: Differentiation among inbred families. US Dep Agric Tech Bull 1090, 65

Wright S, Eaton ON (1929) The persistence of differentiation among inbred families of guinea pigs. US Dep Agric Tech Bull 103, 45

Wright FE, Maier P, Kalin M (1972) Maternal effects on sex chromosome loss in X-rayed mature sperms of Drosophila melanogaster. Arch Genet 45, 53-59

Young MN, Schwartz HE (1981) Nomadic gene families in Drosophila. Cold Spring Harb Symp Quant Biol 45, 629-640

Yukuhiro K, Harada K, Mukai T (1985) Viability mutations induced by the $P$ elements in Drosophila melanogaster. Jpn J Genet 60, 531-537 